\title{
PENGETAHUAN PENERAPAN KESELAMATAN PASIEN (PATIENT SAFETY) PADA PETUGAS KESEHATAN
}

\author{
FLORENCE ANGELINE NAINGGOLAN \\ florenceangeline123@gmail.com
}

\section{LatarBelakang}

Keselamatan pasien merupakan dasar dari pelayanan kesehatan yang baik. Pengetahuan tenaga kesehatan dalam sasaran keselamatan pasien terdiri dari ketepatan identifikasi pasien, peningkatan komunikasi yang efektif, peningkatan keamanan obat yang perlu diwaspadai, kepastian tepat lokasi, prosedur, dan tepat pasien operasi, pengurangan risiko infeksi, pengurangan risiko pasien jatuh.

Proses keperawatan merupakan metode ilmiah yang dipakai dalam memberikan asuhan keperawatan yang professional. Perawat, dimana saja ia bertugas,mengahadapi klie dengan segala macam kasus, dan melayani klien pada semua tingkat usia juga harus menggunakan proses keperawatan. Perawat diharapkan memahami tentang konsep proses keperawatan dan mampu menerapkan serta menyusunkan dalam sebuah dokumen status kesehatan klien (Rohmah, $\mathrm{N}$ dan Adam Walid, S. 2009)

Keselamatan pasien (patient safety) adalah dasar dari pelayanan kesehatan yang baik.

Keselamatan pasien juga menjadi salah satu indikator dalam menilai akreditas institusi pelayanan kesehatan, oleh karena itu keselamatan pasien sangat penting. Namun, jika ditinjau dari insiden keselamatan pasien, keselamatan pasien di berbagai tingkat pelayanan kesehatan masih buruk, baik secara global maupun nasional (Kusek, 2012).

Proses Keperawatan Merupakan suatu metode yang sitematis dan terorganisasi dalam pemberian asuhan keperawatan, yang difokuskan pada reaksi dan respons untuk individu pada suatu kelompok atau perorangan terhadap gangguan kesehatan yang dialami, baik aktual maupun potensial. Proses keperawatan juga dapat diartikan sebagai pendekatan yang digunakan perawat dalam memberikan asuhan keperawatan, sehingga kebutuhan dasar klien dapat terpenuhi. Salah 
satu manfaat dari penerapan proses keperawatan yang baik adalah meningkatkan mutu dan kualitas pelayanan dalam bidang keperawatan Asuhan keperawatan dikatakan baik apabila perawat sudah melaksanakan tahap tahap dalam memberikan asuhan keperawatan kepada pasien yaitu tahap pengkajian, diagnosa , perencanaan, implementasi dan Evaluasi.

\section{Metode}

Metode penulisan yang digunakan adalah Literature Riview, yaitu dengan cara menganalisis, mengeksplorasi serta mengkaji bebas jurnal atau karya tulis ilmiah yang relevan Adapun sumber yang digunakan dalam literature ini menggunakan sumber dari buku teks, jurnal dengan memasukan kata kunci Isu Terkini Terkait Keselamatan Pasien.

\section{Hasil}

Hubungan antara pengetahuan dengan penerapan keselamatan pasien (patient safety), dengan demikian penerapan sasaran keselamatan pasien yang baik selalu didasari oleh pengetahuan petugas yang baik, yang diharapkan petugas bisa menerapkan sasaran keselamatan pasien dengan optimal sehingga memberikan kepuasan kepada pasien.

Penerapan keselamatan pasien dilaksanakan dengan baik maka pelayanan yang mengutamakan keselamatan dan kualitas yang optimal akan memberikan dampak yang luas. Terutama bagi masyarakat akan mendapatkan pelayanan yang lebih berkualitas, aman dan memenuhi harapan mereka. Bagi rumah sakit menjadi nilai tambah untuk pencapaian pelayanan yang berstandar nasional dan internasional.

Pelayanan yang aman dan kualitas juga diharapkan dapat meningkatkan kepercayaan publik kepada rumah sakit. Bagi tenaga kesehatan dapat menumbuhkan nilainilai baru khususnya arti penting penerapan keselamatan pasien dalam setiap aktivitas pelayanan yang diberikan (Agency for Healthcare Research and Quality/AHRQ, 2015). Berdasarkan hal tersebut penulis berpendapat teknik pengawasan seorang kepala ruang mempunyai tanggung jawab yang besar dalam organisasi dan menentukan pecapaian tujuan organisasi dalam hal ini untuk meningkatkan keselamatan pasien dan mencegah terjadinya insiden keselamatan pasien. 


\section{Pembahasan}

Hubungan Pengetahuan dengan Penerapan Keselamatan Pasien. Saran Bagi petugas kesehatan agar lebih meningkatkan pengetahuan tentang penerapan sasaran keselamatan pasien, baik dengan mengikuti pelatihan-pelatihan, seminar- seminar maupun mengikuti workshop secara berkelanjutan, sehingga diharapkan penerapan patient safety dapat diterapkan lebih optimal dan tercipta pelayanan kesehatan yang aman dan sesuai dengan standar sasaran keselamatan pasien. Menurut Bawelle, Silonungan dan Hamel (2013), menyatakan bahwa pengetahuan merupakan faktor penting dalam seseorang mengambil keputusan namun tidak selamanya pengetahuan seseorang bisa menghindarkan dirinya dari kesalahan, misalnya petugas kesehatan yang tingkat pengetahuannya baik tidak selamanya melaksanakan keselamatan pasien dengan baik karena segala tindakan yang akan dilakukan beresiko untuk terjadi kesalahan dalam pelaksanaan sasaran keselamatan pasien.

Keselamatan Pasien (KP) merupakan suatu sistem dimana rumah sakit membuat asuhan pasien lebih aman, mencegah terjadinya cidera yang disebabkan oleh kesalahan akibat melaksanakan suatu tindakan atau tidak mengambil tindakan yang seharusnya diambil. Pada prinsipnya keselamatan pasien bukan berarti harus tidak ada risiko sama sekali agar semua tindakan medis dapat dilakukan.

Rumah Sakit (RS) adalah institusi pelayanan kesehatan bagi masyarakat dengan karateristik tersendiri yang dipengaruhi oleh perkembangan ilmu pengetahuan kesehatan, kemajuan teknologi, dan kehidupan sosial ekonomi masyarakat yang harus tetap mampu meningkatkan pelayanan yang lebih bermutu dan terjangkau oleh masyarakat agar terwujud derajat kesehatan yang setinggi- tingginya, seperti yang dijelaskan dalam UndangUndang Kesehatan Nomor 36 Tahun 2009 dan Undang-Undang Rumah Sakit Nomor 44 Tahun 2009 bahwa rumah sakit wajib melaksanakan pelayanan kesehatan yang aman, bermutu, anti diskriminasi dan efektif, dengan mengutamakan kepentingan pasien. Rumah sakit wajib memenuhi hak pasien memperoleh keamanan dan keselamatan selama dalam perawatan di rumah sakit.

Pentingnya pengetahuan perawat dalam memberikan diagnosa keperawatan agar data yang diperoleh benan - benar akurat karena data tersebut akan menjadi patokan dalam melaksanakan tindakan keperawatan. Adapun faktor-faktor yang mempengaruhi pengetahuan seseorang sebagai berikut : Pendidikan berarti bimbingan yang diberikan seseorang kepada orang lain terhadap suatu hal agar mereka dapat memahami. Tidak dapat dipungkiri bahwa makin tinggi pendidikan seseorang semakin mudah pula mereka menerima informasi, dan pada akhirnya makin banyak pula pengetahuan yang dimilikinya. Sebaliknya, jika seseorang tingkat pendidikannya rendah, akan menghambat perkembangan sikap seseorang terhadap penerimaan informasi dan nilai-nilai baru diperkenalkan. Lingkungan pekerjaan dapat menjadikan seseorang memperoleh pengalaman dan pengetahuan baik secara langsung maupun tidak langsung. Makin lama pekerjaan dilakukan maka akan lebih banyak pengalaman dan pengetahuan diperoleh. 
Pengetahuan adalah fakta, keadaan atau kondisi tentang pengertian mencakup kombinasi dari kesadaran sederhana tentang fakta dan pemahaman tentang bagaimana fakta itu berkaitan satu sama lain. Dalam kode etik keperawatan disebutkan bahwa perawat memiliki tanggung jawab agar senantiasa memelihara mutu pelayanan keperawatan yang tinggi disertai kejujuran profesional yang menerapkan pengetahuan serta ketrampilan keperawatan sesuai dengan kebutuhan klien. Dalam hubungannya dengan teman sejawat, perawat berkewajiban melindungi klien dari tenaga kesehatan yang memberikan pelayanan kesehatan secara tidak kompeten, tidak etis dan ilegal.(Permenkes RI Nomor 1961/Menkes/2011). Keselamatan Pasien (patient safety) merupakan isu global dan nasional bagi rumah sakit, komponen penting dari mutu layanan kesehatan, prinsip dasar dari pelayanan pasien dan komponen kritis dari manajemen mutu (WHO, 2014). Ada lima isu penting yang terkait dengan keselamatan (safety) di rumah sakit yaitu: keselamatan pasien (patient safety), keselamatan pekerja atau petugas kesehatan, keselamatan bangunan dan peralatan di rumah sakit, keselamatan lingkungan (green productivity) dan keselamatan bisnis rumah sakit. Ke lima aspek keselamatan tersebut sangatlah penting untuk dilaksanakan di setiap rumah sakit. Harus diakui kegiatan institusi rumah sakit dapat berjalan apabila ada pasien. Karena itu keselamatan pasien merupakan prioritas utama untuk dilaksanakan dan hal tersebut terkait dengan isu mutu dan citra perumahsakitan (Depkes, 2015, p.17).

Keselamatan adalah suatu system yang membuat asuhan pasien lebih aman, meliputi assasmen resiko, identifikasi dan pengelolaan resiko pasien, peporan dan analisis insiden, kemampuan belajar dari insiden dan tindak lanjutnya, serta implementasi solusi untuk meminimalkan timbulnya resiko dan mencegah terjadinya cedera yang disebabkan oleh kesalahan akibat melaksanakan suatu tindakan atau tidak mengambil tindakan yang seharusnya. Suatu jaminan segala tindakan dan aktivitas yang berhubungan dengan pasien yang dilakukan oleh petugas kesehatan agar berlangsung dengan aman. Memberikan citra yang besar, tanggung jawab sosial moral serta kinerja petugas kesehatan agar mutunya menjadi lebih baik.

Keselamatan pasien akan terus berkembang, yang didefinisikan sebagai upaya maksimal yang dilakukan rumah sakit dalam rangka memberikan pelayanan kepada pasien melalui penerapan metode dan regulasi yang legal serta melalui standar yang terukur untuk meminimalisir kesalahan medis. Keselamatan pasien merupakan tanggung jawab semua pihak yang berkaitan dengan pemberi pelayanan kesehatan. Dalam mencapai tujuan yang berorientasi kepada kepuasan pasien, di samping aspek fasilitas rumah sakit, peranan dokter, paramedis dan non medis menjadi sangat penting karena kinerja mereka akan menentukan persepsi dan kinerja yang dirasakan pasien terhadap pelayanan yang diberikan. Keselamatan pasien merupakan salah satu indikator kualitas pelayanan kesehatan.

Menurut Wulandari, Setyaningrum \& Musafah (2015), meyatakan bahwa masa kerja biasanya dikaitkan dengan waktu mulai bekerja, dimana pengalaman kerja juga ikut menentukan kinerja seseorang. Semakin lama masa kerja maka kecakapan akan lebih baik karena sudah menyesuaikan diri dengan pekerjaannya. Sedangkan menurut Elrifda (2014), bahwa pengalaman 
kerja seseorang dapat mempengaruhi kinerja dalam melakukan tugasnya, demikian pula halnya dalam menjaga keselamatan pasien. Idealnya, seseorang yang telah berpengalaman akan lebih baik dalam penerapan keselamatan pasien.

Pengetahuan tentang patient safety pada petugas kesehatan di puskesmas kedaung wetan kota tangerang dengan jumlah responden sebanyak 50 orang dengan pengetahuan tentang patient safety yang tertinggi dalam kategori Baik yaitu 31 responden (62\%), Berdasarkan penelitian tersebut kita bisa menyimpulkan bahwa petugas kesehatan di Puskesmas Kedaung Wetan Kota Tangerang lebih banyak dengan pengetahuan tentang patient safety yang tertinggi dalam kategori baik.

Menurut (Yusuf Pratama 2017), mengatakan bahwa keselamatan pasien bila dilaksanakan dengan baik maka akan memberikan pelayanan yang mengutamakan keselamatan dan kualitas yang optimal, terutama bagi masyarakat akan mendapatkan pelayanan yang lebih berkualitas, aman dan memenuhi harapan mereka.

Bagi tenaga kesehatan dapat memenuhi nilai-nilai baru khususnya arti penting penerapan keselamatan pasien dalam setiap aktivitas pelayanan yang diberikan.

Patient safety (keselamatan pasien) adalah suatu prosedur atau proses dalam suatu rumah sakit yang memberikan pelayanan pasien yang lebih aman. Dimana dipengaruhi oleh pengetahuan dan penerapan dari perawat pelaksana yang mengutamakan kepentingan dan keselamatan pasien.Prosedur patient safety ini sangat menjamin peningkatan mutu dari rumah sakit.Karena suatu rumah sakit dapat dikatakan baik jika pelayanan untuk keselamatan pasien juga sudah baik (Lestari, 2012).

Hughes (2008) menyatakan bahwa langkah awal memperbaiki pelayanan yang berkualitas adalah keselamatan, sedang kunci dari pelayanan bermutu dan aman adalah membangun budaya keselamatan pasien. Menurut Mitchell dalam Hughes (2008), perawat merupakan kunci dalam pengembangan mutu melalui keselamatan pasien.

keselamatan pasien memerlukan komitmen yang di pengaruhi oleh pengetahuan perawat.

Perawat yang memiliki pengetahuan yang baik akan keselamatan pasien pastinya memiliki sikap yang baik dalam meningkatkan mutu dalam pelayanan kesehatan. Hal ini didukung oleh Majid A (2011) yang mengemukakan bahwa pengetahuan merupakan pangkal dari sikap, sedangkan sikap akan mengarah pada tindakan seseorang.

\section{Penutup}

Untuk mewujudkan patient safety dibutuhkan upaya dan kerjasama berbagai pihak.

Patient safety merupakan upaya dari seluruh komponen sarana pelayanan kesehatan, dan perawat memegang peran kunci untuk mencapainya.

Meningkatkan kemampuan perawat dalam mengkategorikan status kesehatan klien dalam menghitung secara benar dan akurat menggunakan Skala jatuh Morse dalam bentuk pelatihan 
atau kursus dalam Program Patient Safety di Rumah Sakit dan Pendokumentasian yang baik haruslah lebih ditingkatkan, untuk itu perawat secara berkala dan berkesinambungan sehingga asuhan keperawatan dapat diberikan secara komprehensif.

\section{Referensi}

Arumaningrum, D. G (2014). Tingkat Pengetahuan Perawat tentang Patient Safety di Unit Anak RS PKU Muhammadiyah Bantul, RS PKU Muhammadiyah Yogyakarta Unit I, dan RS PKU

Bawelle, S. C., Sinolungan, J. S. V., dan Hamel, R. (2013). Hubungan Pengetahuan dan Sikap Perawat dengan Pelaksanaaan Keselamatan Pasien (Patient Safety) di Ruang Rawat Inap RSUD Liun Kendage Tahuna. Jurnal Keperawatan. Gerardin \& Iin. (2018). Pentingnya Standarisasi Prosedur Keselamatan Pasien Di Puskesmas X Kabupaten Kediri. Jurnal Kesehatan Masyarakat.

Cahyono, Suharjo. (2008). Membangun Budaya Keselamatan Pasien dalam Praktik Kedokteran. Yogyakarta : Kanisius. Depkes RI. (2014). Panduan Nasional Keselamatan Pasien Rumah Sakit. Jakarta : Depkes

Hermanto, W. (2016). Tingkat Pengetahuan Perawat Tentang Patient Safety di Rumah Sakit Adi Husada Surabaya. Adi Husada Nursing Journal. 2(1), 68-69.

Gerardin \& Iin. (2018). Pentingnya Standarisasi Prosedur Keselamatan Pasien Di Puskesmas X Kabupaten Kediri. Jurnal Kesehatan Masyarakat.

Iswati (2013). Penerapan Keselamatan Pasien di Rumah Sakit. Jurnal Keperawatan

Muliana \& Mappanganro. (2016). Hubungan Pengetahuan Dan Sikap Perawat dalam Penerapan Patient safety Goal : Identifikasi pasien di rumah sakit Ibnu Sina YW-UMI Makasar. Jurnal Keperawatan.

Simamora, R. H., \& Nurmaini, C. T. S. (2019). Knowledge of Nurses about Prevention of Patient Fall Risk in Inpatient Room of Private Hospital in Medan. Indian Journal of Public Health Research \& Development, 10(10), 759-763.

Wulandari, N., Setyaningrum, R dan Musafaah, M. (2016). Hubungan Karakteristik Dan Pengetahuan Perawat Dengan Sikap Mendukung Penerapan Program Keselamatan Pasien Di Rsud Banjarbaru. Jurnal Publikasi Kesehatan Masyarakat Indonesia.

Mudayana, A.,A. (2015). Pelaksanaan Patient Safety Oleh Perawat di RS PKU Muhammadiyah Yogyakarta. Jurnal Kesehatan Samodra Ilmu. Vol. 6, No. 2 
Pratama, D. A. (2017). Hubungan Tingkat Pengetahuan Tentang Penerapan Patient Safety Oleh Perawat di RSUD. Jurnal keperawatan. 